\title{
Application of Critical Path Method and Fuzzy Logic in Optimizing Bottled Drinking Water Production
}

\author{
Wanda Wira Yudiarti ${ }^{1}$ and Faiz Ainur Razi ${ }^{2 *}$ \\ ${ }^{1}$ Department of Mathematics, Brawijaya University, Malang, Indonesia \\ ${ }^{2}$ Department of Mathematics, State University of Surabaya, Surabaya, Indonesia \\ Email: ndanda.yudiarti@gmail.com, * faizainurrazi9c@gmail.com
}

\begin{abstract}
Project management is one of the analytical techniques used for planning, scheduling, and making decisions about activities. This is useful so that the project can be implemented optimally and efficiently. Project management can be done by optimizing the network. Network optimization is very important for the production of bottled drinking water (AMDK) "AETA" produced by the PDAM of Kota Madiun. The optimization of the bottled water production network in this study uses the Fuzzy Critical Path Method (FCPM) analysis technique. Optimization of this fuzzy network is carried out to find a critical path in the production of bottled drinking water in order to get an efficient time in the production of 4 types of bottled drinking water, namely glass, $1.5 \mathrm{~L}$ bottles, $600 \mathrm{~mL}$ bottles, and gallons. The results showed that gallon product packaging has a high level of efficiency. In this research, fuzzy data analysis uses trapezoidal fuzzy numbers for bottled drinking water production time. Meanwhile, CPM is used to obtain the most efficient critical path or time in the AMDK production. The combination of these two methods is very helpful in project management so that the scheduling of activity can be run optimally.
\end{abstract}

Keywords: Critical Path method; fuzzy; optimization; project management; scheduling.

\begin{abstract}
Abstrak
Manajemen proyek merupakan salab satu teknik analisis yang digunakan untuk perencanaan, penjadwalan, dan pengambilan keputusan tentang kegiatan. Hal ini bermanfaat agar proyek dapat dilaksanakan secara optimal dan efisien. Manajemen proyek dapat dilakukan dengan mengoptimalkan jaringan. Optimalisasi jaringan sangat penting untuk produksi Air Minum Dalam Kemasan (AMDK) "AETA" yang diproduksi oleh PD AM Kota Madiun. Optimasi jaringan produksi AMDK dalam penelitian ini menggunakan teknik analisis Fuz:y Critical Path Method (FCPM). Optimalisasi jaringan fuzZy ini akan dilakukan untuk mencari jalur kritis dalam produksi air minum dalam kemasan guna mendapatkan waktu yang efisien dalam produksi 4 jenis air minum dalam kemasan yaitu gelas, botol 1.5L, botol $600 \mathrm{~mL}$, dan galon. Hasil penelitian didapat pengemasan produk gallon memiliki tingkat efisien yang tinggi. Dalam penelitian ini, data fuzzy menggunakan bilangan fuzzy trapezoidal untuk waktu produksi AMDK. Sedangkean CPM digunakan untuk. mendapatkan jalur atau waktu kritis yang paling efisien dalam produksi AMDK. Penggabungan antara dua metode ini sangat membantu dalam manajemen proyek sehingga penjadwalan suatu aktivitas bisa berjalan secara optimal.
\end{abstract}

Kata kunci: Critical Path method; fuzzy; manajemen proyek; optimasi; penjadwalan.

\section{INTRODUCTION}

There are a lot of natural resources in Indonesia. One of the wealth owned by Indonesia is the wealth of water. Because Indonesia has many mountains where water sources seem never to stop flowing. Madiun City is one of the cities that has a mountainous area in it. Geographically, Madiun

Submitted February $9^{\text {th }}, 2021$, Revised March $3^{\text {rd }}, 2021$, Accepted for publication March $4^{\text {th }}, 2021$.

This is an open access article under CC-BY-SA license (https://creativecommons.org/licence/by-sa/4.0/) 
City is located in a mountainous area with an area of $33.23 \mathrm{~km} 2$. This causes the city's water sources to be abundant. Two mountains are Mount Wilis and Mount Lawu. Water is a fundamental necessity for almost everything. Freshwater is a basic requirement for humans and wildlife [1]. Besides that, water is a vital element that is essential for human life. Most of the cells in the human body contain water. Therefore, one of the determinants of the quality of human life is by looking at clean water quality. With water, various activities can be carried out properly.

The Regional Drinking Water Company (PDAM) of Madiun City provides facilities for the community to enjoy clean water. Generally, the product that is widely used by the community is the transmission of clean water through pipes. Besides, PDAM also has superior products such as Bottled Drinking Water (AMDK) in the form of glasses or cups, $600 \mathrm{~mL}$ bottles, $1.5 \mathrm{~L}$ bottles, and refill gallons with the product name called AETA. Each production of this product requires a wellcontrolled work system to achieve the economic concept, that is, spending less money but getting maximum profit. Another problem in the production process is the packaging process with less than optimal time efficiency. Thus, the optimal time will be sought with project management.

As the main pillar in many projects and productions, managing projects is important in managing scheduling time. Because in the industrial world, the optimization of production costs greatly affects profits [2]. There are various problems faced with the time management process in industrial activities. This problem can also be overcome by using the formulation of the Critical Path Method (CPM) [3] [4][5]. The CPM is the method used for planning, monitoring, and controlling the project schedule based on the determined critical path [6], [7]. The application of tools, techniques, knowledge, and skills is a function of project management in obtaining the desired results [8][9][10]. The search for the critical path in bottled water production will be combined with fuzzy logic for the most efficient time search. Recently, the science of logic has developed very rapidly in science and technology, namely fuzzy logic. This science works using computational methods by applying human linguistic language and its reasoning process [11]. The output of the fuzzy logic structure for applying science and technology can work like a human mindset [12]. Therefore, in carrying out industrial processes in the field of AMDK, the author will use CPM and Fuzzy logic. The unknown problem that could occur in a practical situation can be managed using this fuzzy CPM [13]. This method is used to obtain the optimal network by using the most efficient time to obtain the maximum benefits in the industrial world. This research is expected to solve the problem of time or scheduling of bottled drinking water through the Fuzzy Critical Path Method. Therefore, project management in the company can be done optimally.

\section{METHOD}

In this study, the application of the Critical Path Method (CPM) with fuzzy time parameters is used to determine the fastest route for packaging bottled drinking water.

\subsection{Sample and Data}

Project activities such as facility maintenance, activity scheduling, building construction, and others can apply CPM [14]. In this research, a mathematical algorithm is used to schedule a series of activities in a project. Samples and data were obtained through data collection at the Tirta Taman Sari 
Regional Drinking Water Company (PDAM), Madiun City, particularly in the Research and Development ( $\&$ D) section of packaging drinking water in AETA packaging.

The activities carried out in PDAM during bottled water production include water storage process, precipitation, filtration, packaging sterilization, pressing, and packaging. These work activities cause a lot of time to be done not optimally. However, in the future, in the results section, a new model in drinking water packaging will be obtained. Meanwhile, the activity codes in using CPM are provided in Table 1.

Table 1. Fuzzy Critical Path Method activity code

\begin{tabular}{ccc}
\hline Activity & Node & Description of Activity \\
\hline A & $0-1$ & Packaging Sterilization \\
\hline B & $0-2$ & Water storage process \\
\hline C & $2-3$ & Precipitation \\
\hline D & $3-4$ & Filtration \\
\hline E & $1-5$ & Press Preparation \\
\hline F & $4-5$ & Packaging Preparation \\
\hline G & $5-6$ & Cup Pressing \\
\hline H & $5-7$ & Bottle Pressing (1.5 L) \\
\hline I & $5-8$ & Bottle Pressing (600ml) \\
\hline J & $5-9$ & Gallon Pressing \\
\hline K & $6-10$ & Cardboard Cup Packaging \\
\hline L & $7-10$ & Cardboard Bottles (1.5 L) Packaging \\
\hline M & $8-10$ & Cardboard Bottles (600ml) \\
& & Packaging \\
\hline N & $9-10$ & Gallon Packaging
\end{tabular}

\subsection{Critical Path Method (CPM)}

The Critical Path Method (CPM) is one of the most widely used project planning and scheduling methods among all systems that use the principle of network formation [15]-[18]. There are several assumptions used in calculating the timing of the network during production [19] i.e. (i) in the ongoing activity, it only consists of the initial event and one terminal event; (2) the initial event occurs on the zero day / time; (3) the latest event occurrence time (TL) equals the earliest event occurrence time (TE) for every event. The fuzzy activity time parameters on CPM are as follows:

\subsubsection{Earliest Time}

The earliest time is defined as the fastest occurring time activity. The earliest and latest times for each activity are calculated based on the forwarding calculations [20]. Based on the fuzzy arithmetic operation of trapezoidal fuzzy numbers, the formula for the earliest time is given as follows:

$$
E_{j}=\max _{i \in D_{j}}\left[E_{i} \oplus t_{i j}\right] \operatorname{dan} E_{1}=L_{1}=0,
$$

where $E_{j}$ is an earliest time from $j$-th node, $D_{j}=\left\{i \mid i \in V\right.$ and $\left.a_{i j} \in A\right\}$ is the set of events obtained from events $j \in V$ and $i<j ; E_{i}$ is an earliest time from $i$-th node; and $t_{i j}$ is a duration from $i$-th node to $j$-th node. 


\subsubsection{Latest Time}

The latest time is the last time or the slowest time for the occurrence of the activity. The formula used to find out the latest time and based on the fuzzy arithmetic operation is as follows [21]:

$$
L_{i}=\min _{j \in H_{i}}\left[L_{j} \ominus t_{i j}\right] \text { and } L_{n}=E_{n}
$$

where $L_{i}$ is a latest time from $\mathrm{i}$-th node; $H_{i}=\left\{j \mid j \in V\right.$ and $\left.a_{i j} \in A\right\}$ is the set of events obtained from events $i \in V$ and $i<j$; and $L_{j}$ is a latest time from $j$-th node.

\subsubsection{Slack Time}

The slack time is the time delay in the activity. The time delay allows activities to go slower than they should be, whether on purpose or accidentally. In this case, the delay in time causes the project to be hampered. The formula used is as follows:

$$
T_{i j}=L_{j} \ominus E_{i} \ominus t_{i j}
$$

where $T_{i j}$ is the slack time from $i$-th activity to $j$-th activity.

\subsubsection{Critical path}

The series of activities of a project must be completed according to a schedule such that the entire project is completed on time. This is the meaning of the application of the critical path [14], [22]. This is the type of activity with the longest path in a network. A typical critical path is marked with a slack time value equal to zero.

\subsection{Fuzzy Set}

Previous researchers used fuzzy logic set theory to analyze project networks [23], [24]. The fuzzy number $\tilde{A}$ is a fuzzy set whose membership function $\mu_{\tilde{A}}$ satisfies the following conditions (a) $\mu_{\tilde{A}}(x)$ is piecewise continuous; (b) $\mu_{\tilde{A}}(x)$ is a convex fuzzy subset; and (c) $\mu_{\tilde{A}}(x)$ is the normality of a fuzzy subset, implying that for at least one element $x_{0}$ the membership grade must be 1 , i.e. $\mu_{\tilde{A}}\left(x_{0}\right)=1$ [25][26].

\subsubsection{Trapezoidal Fuzzy Number}

Definition 1. A fuzzy number with membership function in the form of

$$
\mu_{\tilde{A}}(x)= \begin{cases}\frac{x-a}{b-a} ; & a \leq x<b \\ 1 ; & b \leq x<c \\ \frac{d-x}{d-c} ; & c \leq x \leq d \\ 0 ; & \text { otherwise }\end{cases}
$$

It is called as a trapezoidal fuzzy number $\tilde{A}=(a, b, c, d)$ [27]-[29].

Theorem 1. Let $\tilde{A}=(a, b, c, d)$ be a trapezoidal fuzzy number. Then

$$
\text { Centroid }(\tilde{A})=\frac{\left(c^{2}+d^{2}+c d\right)-\left(a^{2}+b^{2}+a b\right)}{3[(c+d)-(b+a)]}
$$


Proof: From the definition of the centroid method, we may write the following equation:

$$
\text { Centroid }(\tilde{A})=\frac{\int_{a}^{b} \frac{x-a}{b-a} x d x+\int_{b}^{c} x d x+\int_{c}^{d} \frac{d-x}{d-c} x d x}{\int_{a}^{b} \frac{x-a}{b-a} d x+\int_{b}^{c} d x+\int_{c}^{d} \frac{d-x}{d-c} d x}
$$

The triangular fuzzy number theorem (illustrated in Figure 1) valid after the corresponding integral is calculated [30]. From the trapezoidal fuzzy number curve, it can be seen that the trapezoidal fuzzy number is a combination of two triangular fuzzy numbers (e.g. $\tilde{A}_{1}$ and $\tilde{A}_{3}$ ) and a rectangular fuzzy number $\left(\tilde{A}_{2}\right)$. Thus, based on the triangular fuzzy number theorem, it can be written:

$$
\begin{aligned}
& \text { Centroid }\left(\tilde{A}_{1}\right)=\frac{a+2 b}{3} \\
& \text { Centroid }\left(\tilde{A}_{2}\right)=\frac{b+c}{2} \\
& \text { Centroid }\left(\tilde{A}_{3}\right)=\frac{2 c+d}{3}
\end{aligned}
$$

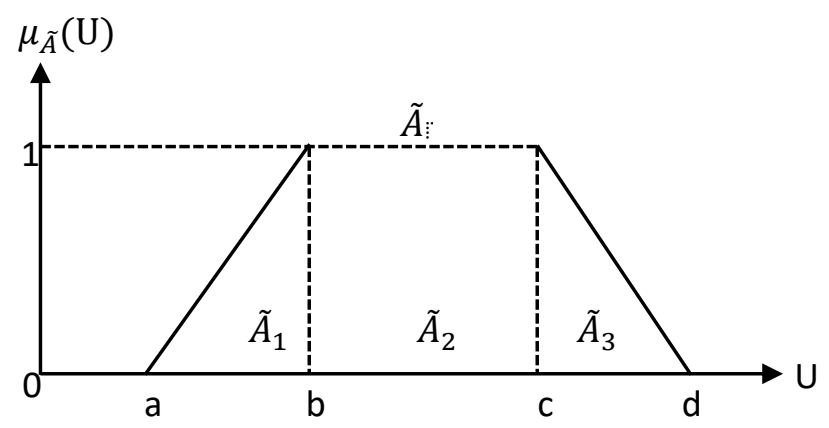

Figure 1. Trapezoidal fuzzy number curve with the division of the centroid.

Let $\tilde{A}$ and $\tilde{B}$ are two trapezoidal fuzzy numbers with quadruple $\left(a_{1}, b_{1}, c_{1}, d_{1}\right)$ and $\left(a_{2}, b_{2}, c_{2}, d_{2}\right)$, where $a_{1} \leq a_{2}, b_{1} \leq b_{2}, c_{1} \leq c_{2}$ and $d_{1} \leq d_{2}$. The fuzzy arithmetic operation of trapezoidal fuzzy numbers $\tilde{A}$ and $\tilde{B}$ can be written as follows [31]:

Fuzzy numbers addition $\oplus:\left(a_{1}, b_{1}, c_{1}, d_{1}\right) \oplus\left(a_{2}, b_{2}, c_{2}, d_{2}\right)=\left(a_{1}+a_{2}, b_{1}+b_{2}, c_{1}+c_{2}, d_{1}+d_{2}\right)$,

Fuzzy numbers subtraction $\ominus:\left(a_{1}, b_{1}, c_{1}, d_{1}\right) \ominus\left(a_{2}, b_{2}, c_{2}, d_{2}\right)=\left(a_{1}-d_{2}, b_{1}-c_{2}, c_{1}-b_{2}, d_{1}-a_{2}\right)$.

\subsubsection{Defuzzification}

The process of converting the fuzzy output into a crisp value is called defuzzification [32]. The defuzzification used in this study is defuzzification using the magnitude method.

Definition 2. Let $\tilde{A}=(a, b, c, d)$ be a trapezoidal fuzzy number such that $a<b<c<d$ where the trapezoidal fuzzy number is then converted into a triangular fuzzy number $\tilde{A}=\left(a, b_{1}=\frac{b+c}{2}, d\right)$ such $a<b_{1}<d$ so that it is obtained the following:

$$
\operatorname{Mag}(\tilde{A})=\frac{a+7 b_{1}+d}{12}
$$




\section{RESULTS AND DISCUSSION}

\subsection{Fuzzy Critical Path Method}

In this research, it is known that the flowchart of drinking water packaging is linear. This result is modified in such a way that the drinking water packaging activity reaches the optimum time. Figure 2 depicts the new model after modification. This model consists of 11 nodes with node 0 being the initial event and node 10 being the terminal event.

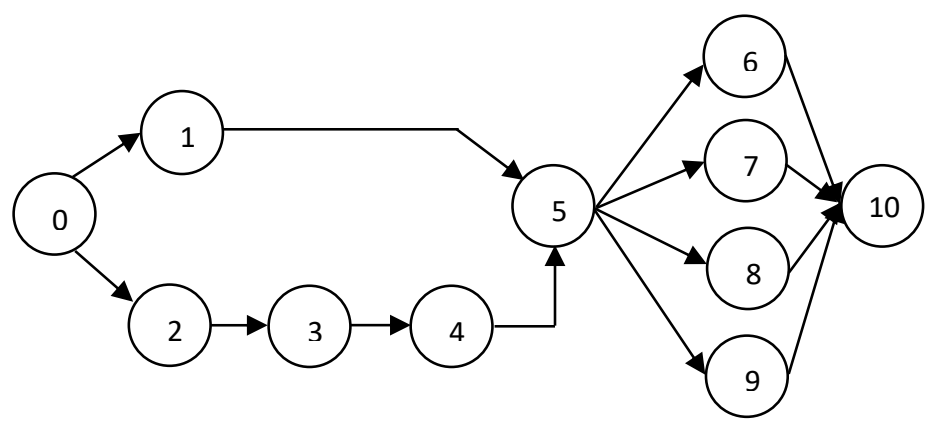

Figure 2. Flowchart modification.

The completion of the model in this case will use the Fuzzy Critical Path Method (FCPM). This method uses fuzzy time which is useful for increasing accuracy in determining the optimum working time. The trapezoidal fuzzy number will be applied to see the possibility of working time. In Table 2, it can be seen about the project network activity fuzzy time (all in minutes) using a trapezoidal fuzzy number.

Table 2. Fuzzy activity time

\begin{tabular}{cc}
\hline Activity & Fuzzy Activity Time \\
\hline $\mathrm{A}$ & $(2,3,6,8)$ \\
\hline $\mathrm{B}$ & $(1430,1438,1443,1448)$ \\
\hline $\mathrm{C}$ & $(5,8,11,13)$ \\
\hline $\mathrm{D}$ & $(25,28,31,35)$ \\
\hline $\mathrm{E}$ & $(1,2,4,6)$ \\
\hline $\mathrm{F}$ & $(0.2,0.3,0.6,0.8)$ \\
\hline $\mathrm{G}$ & $(0.2,0.3,0.5,0.6)$ \\
\hline $\mathrm{H}$ & $(0.2,0.3,0.6,0.8)$ \\
\hline $\mathrm{I}$ & $(0.4,0.6,0.9,1)$ \\
\hline $\mathrm{J}$ & $(0.6,0.8,1.2,1.3)$ \\
\hline $\mathrm{K}$ & $(0.2,0.3,0.6,0.8)$ \\
\hline $\mathrm{L}$ & $(0.6,0.8,1.2,1.3)$ \\
\hline $\mathrm{M}$ & $(0.8,1.3,1.6,1.8)$ \\
\hline $\mathrm{N}$ & $(1,2,4,6)$ \\
\hline
\end{tabular}

The next process finds the earliest fuzzy time, latest fuzzy time, and slack fuzzy time values according to equations (1), (2), and (3) as shown in Table 3. It is necessary to know these values in determining the critical path. The calculated slack fuzzy time in Table 3 is not in the real time but is 
still in the form of fuzzy time. Therefore, it is necessary to do defuzzification. Table 3. The earliest, latest, and slack fuzzy time activities.

Table 3. The earliest, latest, and slack fuzzy time activities

\begin{tabular}{cccc}
\hline Activity & Earliest Fuzzy Time & Latest Fuzzy Time & \multicolumn{1}{c}{ Slack Fuzzy Time } \\
\hline A & $(2,3,6,8)$ & $(-6,-3,3,6)$ & $(1446.2,1464.3,1480.6,1493.8)$ \\
\hline B & $(1430,1438,1443,1448)$ & $(-18,-5,5,18)$ & $(-26,-8,8,26)$ \\
\hline C & $(1435,1446,1454,1461)$ & $(1422,1435,1446,1456)$ & $(-36,-11,11,36)$ \\
\hline D & $(1460,1474,1485,1496)$ & $(1425,1443,1457,1471)$ & $(-36.6,-11.3,11.3,36.6)$ \\
\hline E & $(3,5,10,14)$ & $(1454.2,1470.3,1483.6,1495.8)$ & $(1445.5,1463.9,1481,1494.5)$ \\
\hline F & $(1460.2,1474.3,1485.6,1496.8)$ & $(1459.4,1473.7,1485.3,1496.6)$ & $(-37.3,-11.7,11.7,37.3)$ \\
\hline G & $(1460.4,1474.6,1486.1,1497.4)$ & $(1459.8,1474.1,1485.8,1497.2)$ & $(1446.4,1466,1485.2,1500.7)$ \\
\hline H & $(1460.4,1474.6,1486.2,1497.6)$ & $(1459.6,1474,1485.9,1497.4)$ & $(-37.1,-10.3,15.4,43.1)$ \\
\hline I & $(1460.6,1474.9,1486,5,1497.8)$ & $(1459.6,1474,1485.9,1497.4)$ & $(-37.8,-11,14.6,42.7)$ \\
\hline J & $(1460.8,1475.1,1486.8,1498.1)$ & $(1459.5,1473.9,1486,1497.5)$ & $(-42.3,-13.7,13.7,42.3)$ \\
\hline K & $(1460.6,1474.9,1486.7,1498.2)$ & $(1461,1476.5,1490.5,1503.9)$ & $(-36.4,-9.6,15.9,43.5)$ \\
\hline L & $(1461,1475.4,1487.4,1498.9)$ & $(1460.5,1475.9,1490,1503.5)$ & $(-37.1,-10.3,15.4,43.1)$ \\
\hline M & $(1461.4,1476.2,1488.1,1499.6)$ & $(1460,1475.5,1489.5,1503.3)$ & $(-37.8,-11,14.6,42.7)$ \\
\hline N & $(1461.8,1477.1,1490.8,1504.1)$ & $(1455.8,1473.1,1488.8,1503.1)$ & $(-42.3,-13.7,13.7,42.3)$ \\
\hline
\end{tabular}

\subsection{Defuzzification Result}

After determining the slack fuzzy time, the next step is to convert the trapezoidal fuzzy number to a real number (normal time) using magnitude method in equation (4).

Table 4. Defuzzification values of slack time for fuzzy

\begin{tabular}{cccc}
\hline Activity & Fuzzy Time Activity & Slack Fuzzy Time & Defuzzification Value \\
\hline A & $(2,3,6,8)$ & $(1446.2,1464.3,1480.6$, & \\
\hline B & $(1430,1438,1443,1448)$ & $(-26,-8,8,26)$ & 1103.9 \\
\hline C & $(5,8,11,13)$ & $(-36,-11,11,36)$ & 0 \\
\hline D & $(25,28,31,35)$ & $(-36.6,-11.3,11.3,36.6)$ & 0 \\
\hline E & $(1,2,4,6)$ & $(1445.5,1463.9,1481,1494.5)$ & 1103.9 \\
\hline F & $(0.2,0.3,0.6,0.8)$ & $(-37.3,-11.7,1.7,37.3)$ & 0 \\
\hline G & $(0.2,0.3,0.5,0.6)$ & $(1446.4,1466,1485.2,1500.7)$ & 1106.4 \\
\hline H & $(0.2,0.3,0.6,0.8)$ & $(-37.1,-10.3,15.4,43.1)$ & 1.9875 \\
\hline I & $(0.4,0.6,0.9,1)$ & $(-37.8,-11,14.6,42.7)$ & 1,5 \\
\hline J & $(0.6,0.8,1.2,1.3)$ & $(-42.3,-13.7,13.7,42.3)$ & 0 \\
\hline K & $(0.2,0.3,0.6,0.8)$ & $(-36.4,-9.6,15.9,43.5)$ & 2.4 \\
\hline L & $(0.6,0.8,1.2,1.3)$ & $(-37.1,-10.3,15.4,43.1)$ & 2 \\
\hline M & $(0.8,1.3,1.6,1.8)$ & $(-37.8,-11,14.6,42.7)$ & 1.5 \\
\hline N & $(1,2,4,6)$ & $(-42.3,-13.7,13.7,42.3)$ & 0 \\
\hline
\end{tabular}

Based on Table 4, it can be seen that the critical path is following the defuzzification results for each activity which has value of 0 . In the critical path theory, the critical path is marked with value of 0 at the slack fuzzy time. Thus, the critical path obtained from bottled drinking water packaging activity is B-C-D-F-J-N or according to Figure 2, it can be written as 0-2-3-4-5-9-10. Thus, the optimal values from sequential project implementation are water storage process, precipitation, filtration, packaging 
preparation, gallon pressing, and gallon packing. Packaging of bottled drinking glasses, 1.5L bottles, and $600 \mathrm{~mL}$ bottles produce a relatively long time because these products need time to pack into boxes. Unlike the gallon product that does not require the box packaging.

\section{CONCLUSIONS}

The current theory of fuzzy logic is very influential in human life, one of which is the combination of the Critical Path Method (CPM) and fuzzy logic. This combination is very helpful in the industrial world, for example in the packaging industry for bottled drinking water. This is proved that the trapezoidal fuzzy number can be applied in CPM to get the critical path for bottled water projects. From the research activities carried out in this case, a critical path was obtained sequentially, i.e. the B-C-D-F-J-N activity or in real activity is water storage process, precipitation, filtration, packaging preparation, gallon pressing, and gallon packing. These results were consistent with activities happened in the field where the activities on this critical path are indeed suitable because in the gallon packaging it does not require packaging into boxes like other products so that the time used is optimal. In the future, this research can also apply CPM based on the metric distance ranking of fuzzy numbers.

Acknowledgements: The author would like to thank PDAM Tirta Taman Sari, Madiun City who has helped so that this research can be completed properly.

\section{REFERENCES}

[1] L. Joseph, B. M. Jun, J. R. V. Flora, C. M. Park, and Y. Yoon, "Removal of heavy metals from water sources in the developing world using low-cost materials: A review," Chemosphere, vol. 229, pp. 142-159, 2019, doi: 10.1016/j.chemosphere.2019.04.198.

[2] H. H. Ahmad, "Analysis of business networks in project management by using critical path method (CPM)," J. Interdiscip. Math., vol. 23, no. 4, pp. 851-855, 2020, doi: 10.1080/09720502.2020.1727612.

[3] Y. Takakura, T. Yajima, Y. Kawajiri, and S. Hashizume, "Application of critical path method to stochastic processes with historical operation data," Chem. Eng. Res. Des., vol. 149, pp. 195208, Sep. 2019, doi: 10.1016/j.cherd.2019.06.027.

[4] A. Amalia, M. Dachyar, and Farizal, "Scheduling of Aircraft Design Project: A Comparison of Critical Path Method, Design Structure Matrix and Genetic Algorithm Approaches," in MATEC Web of Conferences, 2018, vol. 248, doi: 10.1051/matecconf/201824803011.

[5] M. Fu, L. Wu, Z. Hong, F. Zhu, H. Sun, and W. Feng, "A critical-path-coverage-based vulnerability detection method for smart contracts," IEEE Access, vol. 7, pp. 147327-147344, 2019, doi: 10.1109/ACCESS.2019.2947146.

[6] H. Deacon and E. Van Der Lingen, "The use of the critical path and critical chain methods in the South African construction industry," Acta Structilia, vol. 22, no. 1, pp. 73-97, 2015.

[7] H. Olivieri et al., "Survey Comparing Critical Path Method, Last Planner System, and LocationBased Techniques," J. Constr. Eng. Manag., vol. 145, no. 12, 2019, doi: 10.1061/(ASCE)CO.1943-7862.0001644.

[8] M. P. Hidayat, M. Dachyar, and Farizal, "Scheduling for Indonesia's Aircraft Wing Structure Design Project with Critical Path Method and Resource-Constrained Project Scheduling," MATEC Web Conf., vol. 248, pp. 4-8, 2018, doi: 10.1051/matecconf/201824803010.

[9] N. Khanlarzade, B. Yousefi Yegane, and I. Nakhai Kamalabadi, "Critical path method for lot streaming problem in flexible job shop environment," Int. J. Eng. Trans. B Appl., vol. 30, no. 2, 
pp. 1276-1285, 2017.

[10] M. A. Adibhesami, A. Ekhlassi, A. Mohebifar, and A. M. Mosadeghrad, "Improving time-cost balance in critical path method (CPM) using Dragonfly Algorithm(DA)," Int. J. Ind. Eng. Prod. Res., vol. 30, no. 1, pp. 187-194, 2019, doi: 10.22068/ijiepr.30.2.187.

[11] A. Alesyanti, R. Ramlan, H. Hartono, and R. Rahim, "Ethical decision support system based on hermeneutic view focus on social justice," Int. J. Eng. Technol., vol. 7, no. 2, pp. 74-77, 2018.

[12] Z. Niswati, F. A. Mustika, and A. Paramita, "Fuzzy logic implementation for diagnosis of Diabetes Mellitus disease at Puskesmas in East Jakarta," J. Phys. Conf. Ser., vol. 1114, no. 1, 2018, doi: 10.1088/1742-6596/1114/1/012107.

[13] V. Anusuya and P. Balasowandari, "Critical Path with Various Distances of Type-2 Fuzzy Numbers," Intern. J. Fuzzy Math. Arch., vol. 13, no. 1, pp. 1-7, 2017.

[14] F. A. Razi and W. W. Yudiarti, "Network Optimization of Packaging Water Factory 'Aeta' by Using Critical Path Method (CPM) in Tirta Taman Sari Drinking Water Company, Madiun City," J. Varian, vol. 4, no. 1, pp. 11-18, 2020, doi: 10.30812/varian.v4i1.834.

[15] E. Forcael, V. González, F. Orozco, A. Opazo, Á. Suazo, and P. Aránguiz, "Application of problem-based learning to teaching the critical path method," J. Prof. Issues Eng. Educ. Pract., vol. 141, no. 3, pp. 1-11, 2015, doi: 10.1061/(ASCE)EI.1943-5541.0000236.

[16] A. G. Mahardika, H. Fadriani, Muntiyono, S. Afiyah, and G. D. Ramady, "Analysis of Time Acceleration Costs in Level Building Using Critical Path Method," J. Phys. Conf. Ser., vol. 1424, no. 1, 2019, doi: 10.1088/1742-6596/1424/1/012025.

[17] P. H. Soe and T. M. Htike, "Critical path analysis programming method without network diagram," MATEC web Conf., vol. 01027, pp. 1-4, 2018.

[18] M. Shurrab, "Traditional Critical Path Method versus Critical Chain Project Management: A Comparative View," Int. J. Econ. Manag. Sci., vol. 04, no. 09, pp. 4-9, 2015, doi: 10.4172/21626359.1000292.

[19] D. R. Kiran, "Critical path method," in Production Planning and Control, Elsevier, 2019, pp. 457471.

[20] S. Zareei, "Project scheduling for constructing biogas plant using critical path method," Renew. Sustain. Energy Rev., vol. 81, no. May 2017, pp. 756-759, 2018, doi: 10.1016/j.rser.2017.08.025.

[21] A. A. Goryachev, A. V. Goryachev, A. V. Monakhov, and N. E. Novakova, "Calculating Critical Path: Comparison of heuristic methods," Proc. 19th Int. Conf. Soft Comput. Meas. SCM 2016, pp. 10-13, 2016, doi: 10.1109/SCM.2016.7519668.

[22] M. ATM and T. UM, "Using Critical Path Method for Making Process Layout of a T-Shirt within Earliest Finish Time," J. Text. Sci. Eng., vol. 07, no. 05, 2017, doi: 10.4172/21658064.1000316.

[23] M. K. Mehlawat and P. Gupta, "A new fuzzy group multi-criteria decision making method with an application to the critical path selection," Int. J. Adv. Manuf. Technol., vol. 83, no. 5-8, pp. 1281-1296, 2016, doi: 10.1007/s00170-015-7610-4.

[24] Y. Dorfeshan, S. M. Mousavi, V. Mohagheghi, and B. Vahdani, "Selecting project-critical path by a new interval type-2 fuzzy decision methodology based on MULTIMOORA, MOOSRA and TPOP methods," Comput. Ind. Eng., vol. 120, pp. 160-178, 2018, doi: 10.1016/j.cie.2018.04.015.

[25] D. S. Dinagar and N. Rameshan, "A new approach for fuzzy critical path method using octagonal fuzzy numbers," Int. J. Pure Appl. Math., vol. 119, no. 13, pp. 357-364, 2018.

[26] I. Journal, "A Study on Critical Path Method Using Interval Valued Fuzzy Numbers," vol. 4, no. 4, pp. 293-301, 2016.

[27] C. Hu and D. Liu, "Improved Critical Path Method with Trapezoidal Fuzzy Activity 
Durations," J. Constr. Eng. Manag., vol. 144, no. 9, 2018, doi: 10.1061/(ASCE)CO.19437862.0001541.

[28] C. Rajendran and M. Ananthanarayanan, "Fuzzy Criticalpath Method with Hexagonal and Generalised Hexagonal Fuzzy Numbers Using Ranking Method," Int.J. Appl. Eng. Res., vol. 13, no. 15, pp. 11877-11882, 2018.

[29] A. Rusu, "A FUZZY APPROACH TO CRITICAL PATH METHOD IN," Univ. Teh. „Gheorghe Asachi” din Iaşi, vol. 63, no. 67, 2017.

[30] P. Jayagowri and G. Geetharamani, "Using metric distance ranking method to find intuitionistic fuzzy critical path,” J. Appl. Math., vol. 2015, 2015, doi: 10.1155/2015/952150.

[31] V. P. raj and P. J. Paul, "A Study on Fuzzy Critical Path Method Based On Metric Distance Ranking Of Fuzzy Numbers with Conventional Method," Int. J. Math. Trends Technol., vol. 40, no. 3, pp. 230-236, 2016, doi: 10.14445/22315373/ijmtt-v40p528.

[32] Y. Dorfeshan and S. M. Mousavi, "A new interval type-2 fuzzy decision method with an extended relative preference relation and entropy to project critical path selection," Int. J. Fuzzy Syst. Appl., vol. 8, no. 1, pp. 19-47, 2019, doi: 10.4018/IJFSA.2019010102. 